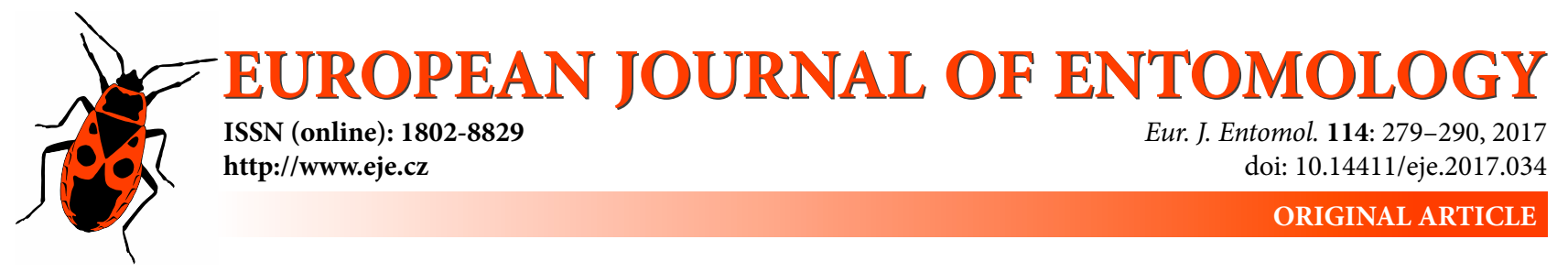

\title{
Indochinese Polydictya lanternflies: Two new species from Vietnam, identification key and notes on $P$. vietnamica (Hemiptera: Fulgoromorpha: Fulgoridae)
}

\author{
JÉRÔMe CONSTANT ${ }^{1}$ and Hong-Thal PHAM ${ }^{2}$ \\ ${ }^{1}$ Royal Belgian Institute of Natural Sciences, O.D. Phylogeny and Taxonomy, Entomology, Vautier street 29, B-1000 Brussels, \\ Belgium; e-mail: jerome.constant@naturalsciences.be \\ ZooBank Author LSID: 6E6072A1-9415-4C8D-8E60-2504444DB290 \\ 2 Vietnam National Museum of Nature, Vietnam Academy of Science and Technology, 18 Hoang Quoc Viet Street, Hanoi, \\ Vietnam; e-mail: phamthai@vnmn.vast.vn \\ ZooBank Author LSID: E34CB863-7E3B-4E8F-8738-B41C07D9F5F9
}

Key words. Hemiptera, Fulgoridae, Polydictya, lanternbug, planthopper, taxonomy, new species, key, citizen science, Indochina

\begin{abstract}
Two new species of Polydictya Guérin-Méneville, 1844 from Vietnam, $P$. grootaerti sp. n. from Central Vietnam and $P$. drumonti sp. n. from North Vietnam, are described and compared with the closest species, $P$. chantrainei Nagai \& Porion, 2004 and $P$. kuntzi Nagai \& Porion, 2004. The male genitalia are described and illustrated for the two new species as well as for $P$. vietnamica Constant \& Pham, 2008 for the first time. Habitus details and photographs, a distribution map and photographs of specimens in nature when available, are provided. The occurrence of $P$. vietnamica from Thailand and Northeast India, noted here for the first time based on photographs taken in nature, requires confirmation based on the examination of specimens. An identification key to the species of Polydictya from the Indochinese region is provided.
\end{abstract}

ZooBank Article LSID: 4DD7B940-02D7-426B-A666-8791F30CC5C9

\section{INTRODUCTION}

The genus Polydictya was erected by Guérin-Méneville (1844) to accommodate one species, Eurybrachys basalis Hope, 1843, described from Sylhet (Bangladesh). Species were progressively added to the genus, including Polydictya krisna Kirkaldy, 1902, the type species of Thaumastodictya Kirkaldy, 1902 from Sri Lanka (Kirkaldy, 1902), when this genus was synonymized under Polydictya by Distant (1906). More recently, Lallemand (1963), Nagai \& Porion (1996, 2004), Constant \& Pham (2008), Constant (2009, 2010, 2015, 2016) Chew Kea Foo et al. (2010) and Bosuang et al. (2015) added new species and proposed nomenclatural changes within the genus.

The genus presently contains 28 species (Bourgoin, 2016). It is distributed in the Oriental region: from Sri Lanka to northern India, Thailand, Vietnam, southwards to Sulawesi and its adjacent islands through Indonesia, but it is not recorded from the Philippines.

Five species are currently recorded from the Indochinese Peninsula: P. basalis (Hope, 1843), P. chantrainei Nagai \& Porion, 2004, P. johannae Lallemand, 1956, P. tricolor
(Westwood, 1845) and P. vietnamica Constant \& Pham, 2008 (Nagai \& Porion, 1996; Constant \& Pham, 2008). P. basalis and P. tricolor were mentioned by Distant (1918) from "Indochina" (without further details), and from Vietnam (again without a precise location) by Nagai \& Porion (1996). The latter authors probably based their data on Distant's (1918) paper but, as Indochina (i.e. former French Indochina in this case) actually includes not only Vietnam but also Laos and Cambodia, the presence of the species in Vietnam was not actually ascertained. However, the presence of $P$. tricolor in Vietnam was confirmed by a specimen from Cuarao (Nghe An province) in the BMNH collection (M. Webb, pers. comm. 2016).

The study of recent material in the collections of RBINS, UDCC and VNMN led to the discovery of two new species, which are here described and illustrated, and of a male specimen of $P$. vietnamica, allowing the description of the male genitalia of this species for the first time, for which additional material also allows an update of the distribution. An identification key to the Polydictya species from the Indochinese region is provided. 


\section{MATERIALS AND METHODS}

The male genitalia were dissected as follows: The pygofer was cut from the abdomen of the softened specimen with a needle blade, then heated for about one hour in a $10 \%$ solution of potassium hydroxide $(\mathrm{KOH})$. The aedeagus was dissected with a needle blade and all pieces examined in ethanol and then the whole placed in glycerine for preservation. Observations were done using a Leica MZ8 stereomicroscope. Pictures were taken with a Canon EOS 700D camera with Sigma DG Macro lens, stacked using software CombineZ and optimized with Adobe Photoshop CS3. The phallus was not inflated due to the difficulty of obtaining good and replicable results and because it is not indispensable for separating the species in the genus Polydictya.

For the transcription of the labels of the types, each single label is enclosed in square brackets.

The measurements are as in Constant (2004) and the following abbreviations are used: BF - maximum breadth of the frons; BTg - maximum breadth of the tegmen; BV - maximum breadth of the vertex; LF - length of the frons in median line; LT - total length (apex of head to apex of tegmina); LTg - maximum length of the tegmen; LV - length of the vertex in median line.

Acronyms used for the collections: BMNH - Natural History Museum, London, United Kingdom; RBINS - Royal Belgian Institute of Natural Sciences, Brussels, Belgium; UDCC - University of Delaware, Insect Reference Collection, Newark, Delaware, U.S.A.; VNMN - Vietnam National Museum of Nature, Hanoi, Vietnam.

\section{RESULTS}

\section{Taxonomy}

\section{Family Fulgoridae Latreille, 1807}

\section{Genus Polydictya Guérin-Méneville, 1844}

Polydictya Guérin-Méneville, 1844: 358. Type species: Eurybrachys basalis Hope, 1843 by monotypy.

Thaumastodictya Kirkaldy, 1902: 307. Type species: Polydictya krisna Kirkaldy, 1902 by original designation (junior synonym of Polydictya pantherina Gerstaecker, 1895, see Nagai \& Porion, 1996).

Catalogue. Polydictya: Walker 1851: 289 [list of species]. — Stål 1866: 135 [key]. — Atkinson 1885: 155 [described]. Distant 1888: 487 [compared with Myrilla Distant, 1888]. Karsch 1890: 63 [compared to Anecphora Karsch, 1890]. — Gerstaecker 1895: 10 [compared to Holodictya Gerstaecker, 1895]. — Kirkaldy 1902: 307 [compared to Thaumastodictya Kirkaldy, 1902]. - Melichar 1903: 71 [erroneous synonymy with Chalia Walker, 1858]. - Distant 1906: 199 [key to Oriental genera], 215 [described, senior synonym of Thaumastodictya]. - Kirkaldy 1907: 59 [note on publication date]. - Schmidt 1907: 113 [compared to Myrilla, copied from Distant 1888]. — Jacobi 1910: 101 [compared to Coelodictya Jacobi, 1910]. — Schmidt 1912: 71 [compared to Coelodictya and Holodictya, comments on species]. — Metcalf, 1947: 84 [catalogued]. — Lallemand 1963: 7 [key to genera], 14 [key to species]. — Nagai \& Porion 1996: 13 [list of species, synonymies]. - Constant \& Pham 2008 [notes]. - Constant 2009 [notes, key to species with hind wings red basally]. — Constant 2010 [notes].

Thaumastodictya: Melichar 1903: 71 [additional description]. — Distant 1906a: 215 [junior synonym of Polydictya].

Diagnosis. The characters defining this genus are given by Lallemand (1963), i.e., head broad, slightly narrower than the pronotum; frons as long as broad, not carinate, largely rounded dorsally, broadened above clypeus and much broader than the latter; vertex at least 4 times broader than long, excavate; tegmina at least 2.5 times longer than broad, densely reticulate; clavus closed with vein $\mathrm{A} 1+\mathrm{A} 2$ extending up to sutural margin; hind wings almost entirely reticulate; anterior tibiae as long as femora, sometimes slightly foliaceous; hind tibiae with 4-6 lateral spines.

\section{Polydictya drumonti sp. $\mathrm{n}$.}

(Figs 1, 2, 9)

ZooBank taxon LSID:

63549734-1129-49F0-83F5-1549747607BE

Diagnosis. This species can be separated from all other Polydictya species by the following combination of characters: (1) tegmina pale rosy-brown densely covered with irregular black-brown marking; black spots better defined and more spaced on basal 1/3 (Fig. 1A); (2) hind wings red with apical $1 / 3$ and sutural margins brown and some small black spots inside the red area (Fig. 1A); (3) frons regularly rounded in dorsal view, not projecting anteriorly (Fig. 1B), yellow-brown (Fig. 1D); (4) anterior tibiae not laminate, black (Fig. 1A, C); (5) abdomen mostly black dorsally (Fig. 1A); (6) genital segments red.

The closest species are $P$. chantrainei (Thailand, Malaysia), P. grootaerti sp. n. (Vietnam) and P. kuntzi (Borneo), from which $P$. drumonti can be separated by characters (2) (the three other species do not have black spots inside the coloured area on the posterior wings) and (5) (the abdomen of the three other species is largely or entirely red dorsally).

Description. Measurements and ratios: LT: $\widehat{\sigma}(\mathrm{n}=5)$ : $28.7 \mathrm{~mm}$ (27.2-30.0); LTg/BTg = 3.0; $\mathrm{BV} / \mathrm{LV}=4.4 ; \mathrm{LF} /$ $\mathrm{BF}=0.71$.

Head. Pale yellow-brown with apex of clypeus brown and infraocular tubercle red (Fig. 1B, D, F); vertex curved and deeply grooved transversely with lowest point in middle, and with all 4 margins carinate (Fig. 1B); frons slightly visible from above (Fig. 1B), convex, smooth, subquadrate with impressed, S-shaped longitudinal groove along lateral margin, starting in front of eye (Fig. 1D); clypeus slightly narrower and shorter than frons (Fig. 1D); labium elongate, dark brown, surpassing metacoxae (Fig. 1C); antennae yellow-brown with scape cylindrical, elongate; pedicel bulbous (Fig. 1D, F).

Thorax. Yellow-brown; mesonotum darker than pronotum with a pair of paler, yellowish markings on each side of median line (Fig. 1B, F); pro-, meso- and metasternites brown (Fig. 1C, D); pronotum with transverse wrinkles, longitudinal carina and pair of impressed points on disc; mesonotum smooth with disc wrinkled and obsolete peridiscal carinae; scutellum slightly impressed on disc (Fig. 1B, F); tegulae yellow-brown (Fig. 1B, F).

Tegmina (Fig. 1A, C, E). Pale yellow-brown with basicostal angle whitish, basal 1/4 tinged with rosy, large black markings on basal 1/3 often merging together, 3 large black to dark-brown markings and groups of smaller spots on costal cell sometimes merging together; apical half with veins yellowish and cells dark brown, paler towards apex, 

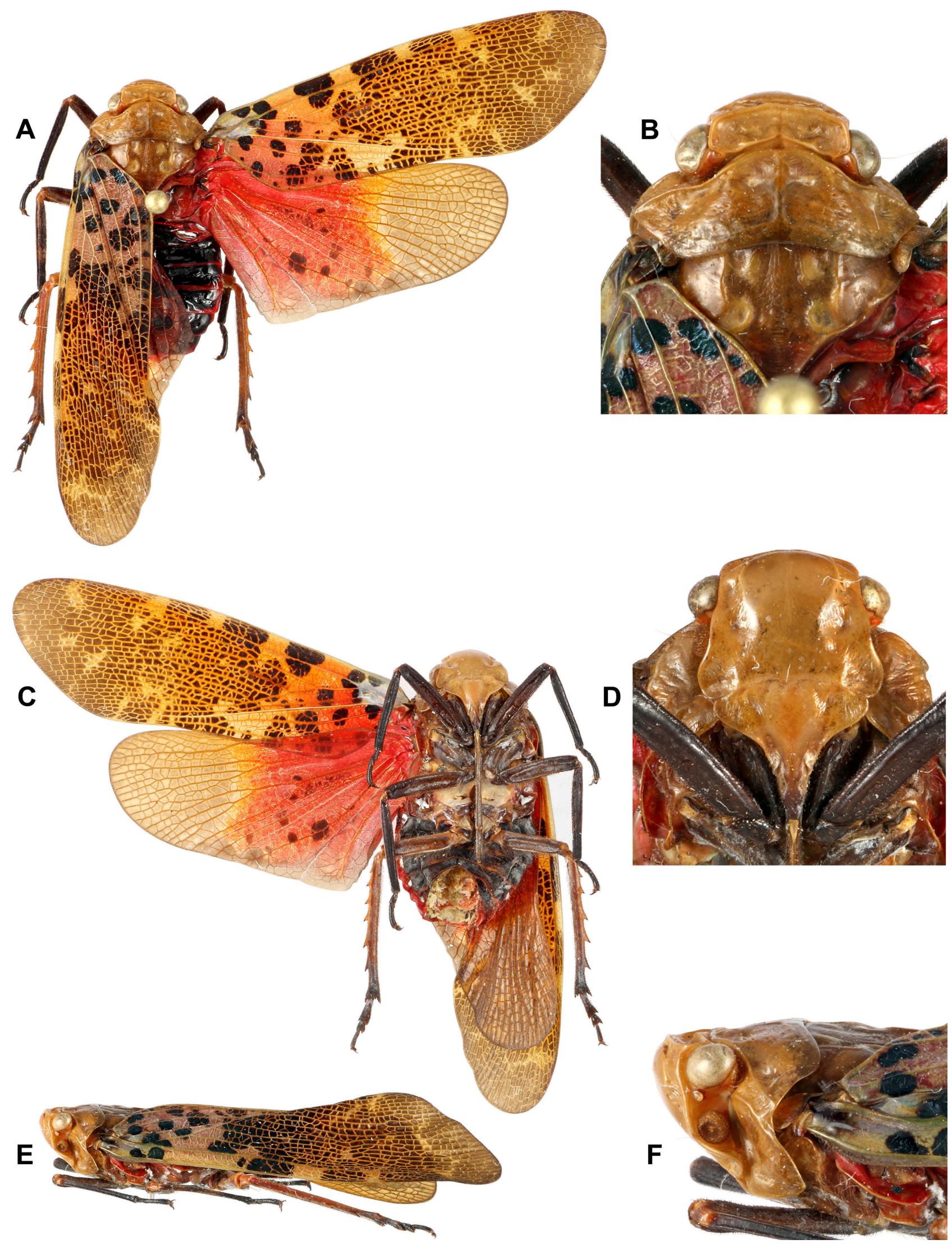

Fig. 1. Polydictya drumonti sp. n., male holotype. A - habitus, dorsal view; B - head, pro- and mesonotum, dorsal view; C - habitus, ventral view; $\mathrm{D}$ - frons, normal view; $\mathrm{E}$ - habitus, lateral view; $\mathrm{F}$ - head and prothorax, lateral view.

and with some irregular yellow-brown markings; costal and sutural margins subparallel, apex obliquely rounded.
Hind wings (Fig. 1A, C). Broader than tegmina. Brown on apical half and along sutural margin; basal half bright 


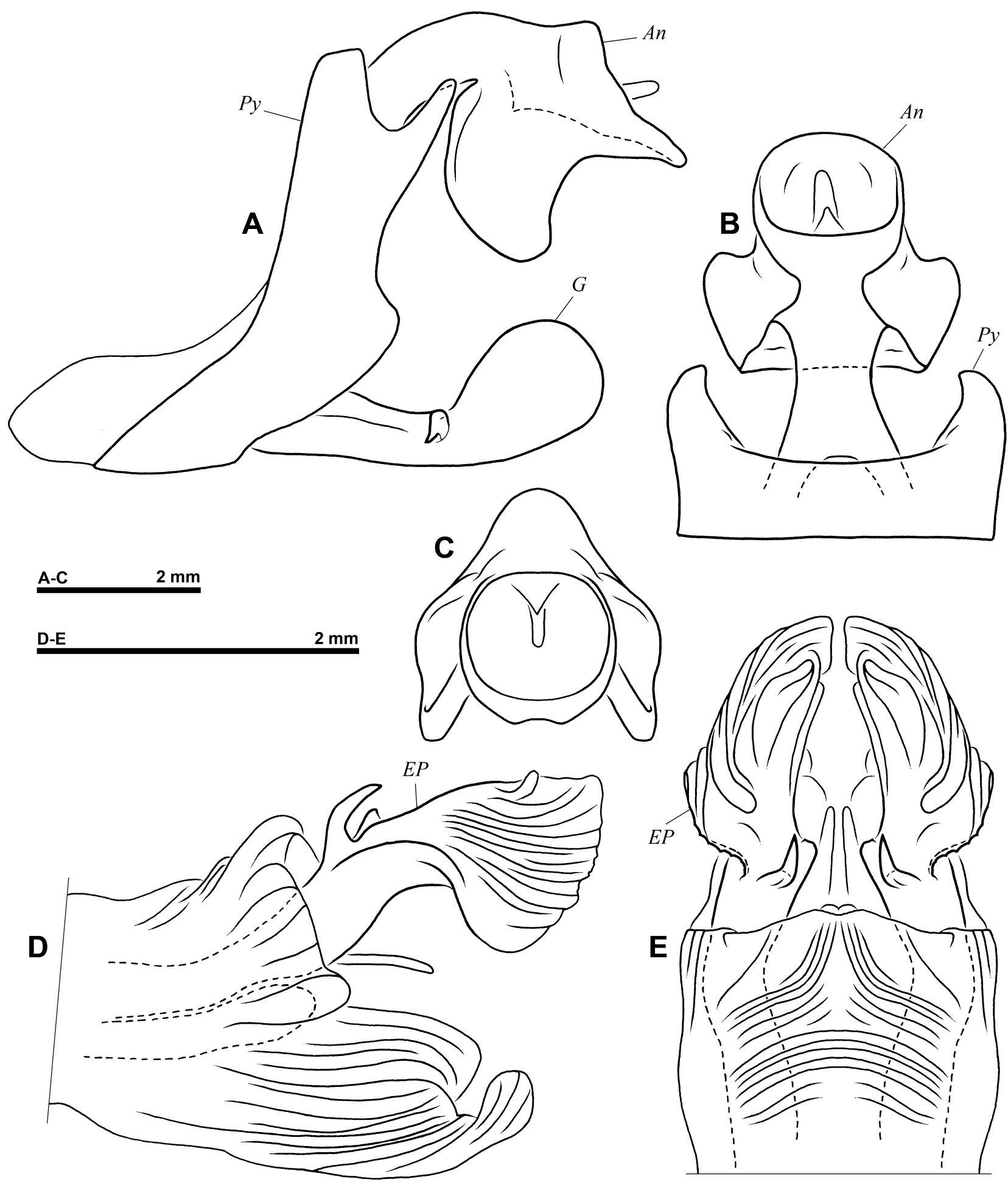

Fig. 2. Polydictya drumonti sp. n., holotype, male genitalia. A - pygofer, anal tube and gonostylus, left lateral view; B - anal tube and pygofer, dorsal view; C - apex of anal tube, postero-dorsal view; D - aedeagus, lateral view; E - aedeagus, dorsal view. An - anal tube; $E P$ - endosomal process of aedeagus; $G$ - gonostylus; $P y-$ pygofer.

red with small irregular black markings; transverse yellowish-orange area between red and brown parts.

Legs (Fig. 1A, C). Elongate and slender with pro- and mesotibiae not foliaceaous. Anterior and middle legs black-brown with protibiae and pro- and mesotarsi black, and mesotibiae with 2 obsolete paler rings. Metafemora yellow-brown dorsally and brown ventrally; metatibiae yellow-brown with apex brown; metatarsi dark brown. Metatibiae with 6 lateral and 7 apical spines.

Abdomen (Fig. 1A, C). Black with lateral pleura and intersegmental membranes bright red. Posterior margin of tergites and sternites very narrowly bordered with red.

Male genitalia. Pygofer, anal tube and gonostyli red; pygofer higher than long, with posterior margin strongly 


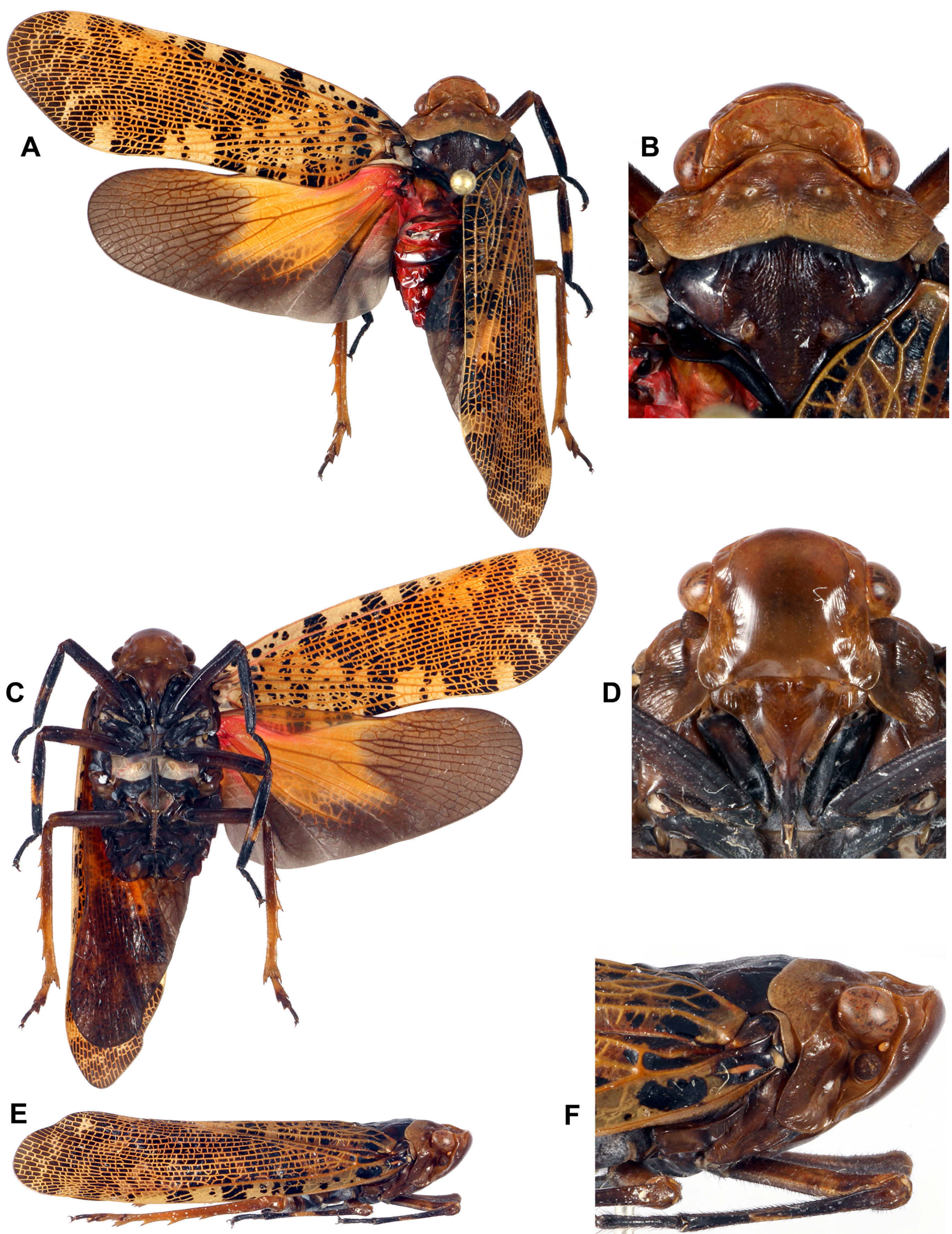

Fig. 3. Polydictya grootaerti sp. $\mathrm{n}$., female paratype. A - habitus, dorsal view; $\mathrm{B}$ - head, pro- and mesonotum, dorsal view; $\mathrm{C}-\mathrm{habitus,}$ ventral view; D - frons, normal view; E - habitus, lateral view; F - head and prothorax, lateral view.

sinuate in lateral view and with strong posterodorsal process directed dorso-posteriorly and slightly hooked internally towards apex (Fig. 2A-B). Anal tube rather massive and short, 1.25 times longer than broad in dorsal view, broader at about half of total length, at level of ventrolateral processes, strongly curved ventrally near base (Fig. 


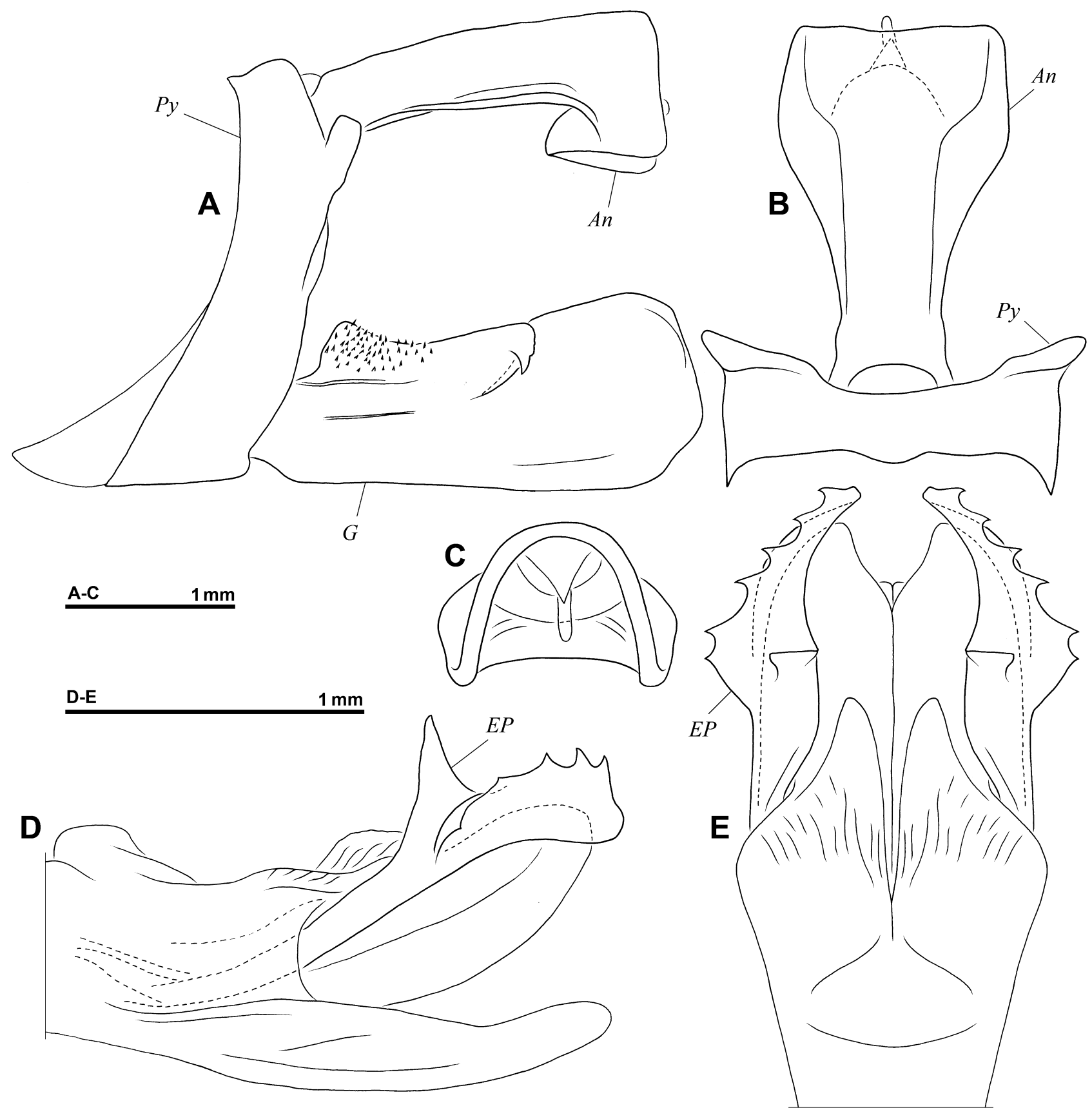

Fig. 4. Polydictya grootaerti sp. n., male holotype, genitalia. A - pygofer, anal tube and gonostylus, left lateral view; B - anal tube and pygofer, dorsal view; $\mathrm{C}$ - apex of anal tube, postero-dorsal view; D - aedeagus, lateral view; E - aedeagus, dorsal view. An - anal tube; $E P$ - endosomal process of aedeagus; $G$ - gonostylus; $P y-$ pygofer.

2A-B); lateral margins strongly projecting ventrally into a large lobe with posterior margin concave; posterior margin rounded in dorsal view (Fig. 2B) and slightly notched ventrally in posterodorsal view (Fig. 2C). Aedeagus (Fig. 2D-E) with endosomal processes with a strong, dorsal, hooked tooth projecting dorso-posteriorly. Apex of endosomal process membranous.

Type material. VIETNAM. Holotype $\widehat{\delta}$ : [Coll. I.R.Sc.N.B., Vietnam, Lao Cai prov., Sa Pa Mt, 1600 m, ix.2015, local collector] (RBINS). Paratypes (4 $\widehat{\delta})$ : 3 $\delta^{\lambda}$ : same data as holotype (2 in RBINS, 1 in VNMN); 1 $\overbrace{}^{\Uparrow}$ : [Coll. I.R.Sc.N.B., Vietnam, Ha Giang, vi.2014, I.G.: 32.899] (RBINS). Coordinates of Sa Pa: $22^{\circ} 21^{\prime} \mathrm{N} 103^{\circ} 52^{\prime} \mathrm{E}$; Ha Giang: $22^{\circ} 50^{\prime} \mathrm{N} 104^{\circ} 59^{\prime} \mathrm{E}$.
Etymology. The species epithet refers to our colleague Alain Drumont (RBINS), who kindly donated the first known specimen of this new species.

Distribution. Known from North Vietnam: $\mathrm{Sa} \mathrm{Pa}$ and $\mathrm{Ha}$ Giang (Fig. 9A).

\section{Polydictya grootaerti sp. $\mathbf{n}$.}

(Figs 3, 4, 5, 9)

ZooBank taxon LSID:

B7CBBEAB-2D49-4BFC-B322-A206CCF378F7

Diagnosis. This species can be separated from all other species of Polydictya by the following combination of 

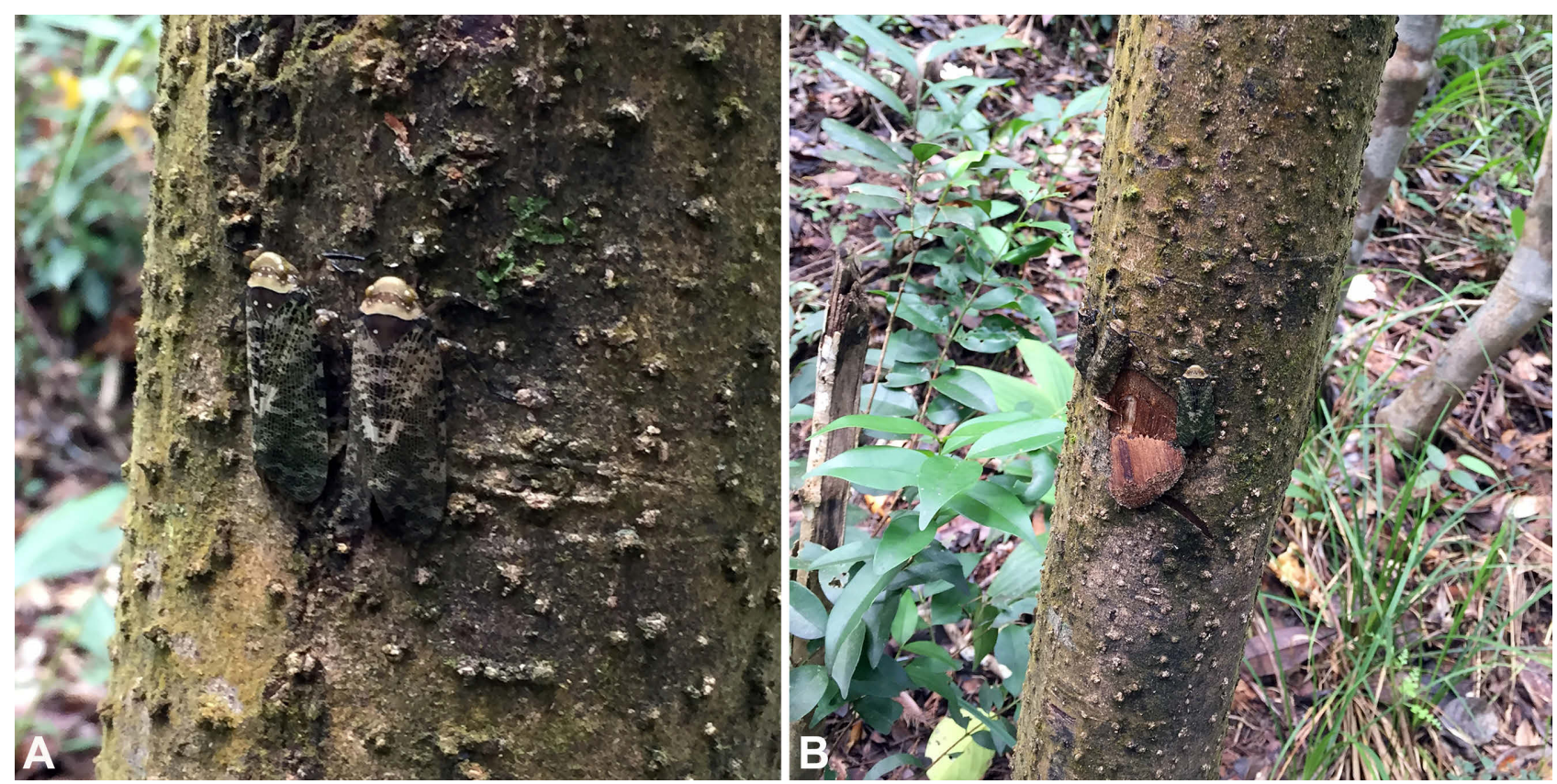

Fig. 5. Polydictya grootaerti sp. n., A-B, in nature, Bach Ma National Park, 9.x.2015 (photographs $\odot$ H.T. Pham).

characters: (1) tegmina pale yellow-brown largely covered with irregular brown-black markings (Fig. 3A); (2) hind wings bright orange with apical $1 / 3$ and large sutural band dark brown; basal angle bright red (Fig. 3A); (3) frons regularly rounded in dorsal view, slightly projecting anteriorly (Fig. 3B), yellow-brown (Fig. 3D); (4) anterior tibiae not laminate, with obsolete paler ring (Fig. 3A, C); (5) abdomen red with middle black dorsally (Fig. 3A); (6) genital segments orange.

The closest species are P. chantrainei (Thailand, Malaysia), P. drumonti sp. n. (Vietnam) and P. kuntzi (Borneo), from which P. grootaerti can be separated by character (2) (the three other species do not have a bright red patch at the base of a bright orange coloured area on the posterior wings) and (5) (in P. chantrainei the dorsum of the abdomen is entirely red, in P. drumonti it is entirely black). It can also be separated from $P$. kuntzi by the black abdominal sternites (red in P. kuntzi).

Description. Measurements and ratios: LT: $\widehat{O}(\mathrm{n}=1)$ : $23.4 \mathrm{~mm}$; $+(\mathrm{n}=4): 27.6 \mathrm{~mm}(26.0-28.8) ; \mathrm{LTg} / \mathrm{BTg}=3.0$; $\mathrm{BV} / \mathrm{LV}=3.56 ; \mathrm{LF} / \mathrm{BF}=0.82$.

Head. Pale yellow-brown with apex of clypeus brown (Fig. 3B, D, F); vertex curved and deeply grooved transversely with lowest point in middle, and with all 4 margins carinate (Fig. 3B); frons very slightly visible from above (Fig. 3B), convex, smooth, subquadrate with impressed, Sshaped longitudinal groove along lateral margin, starting in front of eye (Fig. 3D); clypeus slightly narrower and shorter than frons (Fig. 3D); labium elongate, dark brown, surpassing metacoxae (Fig. 3C); antennae brown with scape cylindrical, elongate; pedicel bulbous (Fig. 3D, F).

Thorax. Pronotum pale yellow-brown with 4 paler spots; mesonotum black-brown with a pair of paler, yellowish markings on each side of median line, at base of scutellum (Fig. 3B, F); pro-, meso- and metasternites black-brown
(Fig. 3C); pronotum with transverse wrinkles, obsolete longitudinal carina on basal half and 4 impressed points on disc; mesonotum smooth with disc longitudinally wrinkled and obsolete peridiscal carinae; scutellum slightly impressed on disc (Fig. 3B, F); tegulae yellow-brown (Fig. 3B, F).

Tegmina (Fig. 3A, C, E). Pale yellow-brown largely covered with irregular black markings formed by black cells, 5 black markings on costal cell; all veins yellowish; pale yellow marking at apex of clavus; costal and sutural margins subparallel, apex obliquely rounded.

Hind wings (Fig. 3A, C). Broader than tegmina. Apical half and broad band along sutural margin brown; basal half bright orange with basal angle red.

Legs (Fig. 3A, C). Elongate and slender with pro- and mesotibiae not foliaceaous. Anterior and middle legs blackbrown, with pro- and mesotibiae with one yellowish ring. Metafemora yellow-brown dorsally and brown ventrally; metatibiae yellow-brown with base brown; metatarsi yellow-brown. Metatibiae with 5-6 lateral and 7 apical spines.

Abdomen (Fig. 3A, C). Black ventrally; dorsum bright red with large black marking on middle.

Male genitalia. Pygofer, anal tube and gonostyli orange; pygofer higher than long, with posterior margin slightly curved in lateral view and showing spatulate dorsolateral process directed dorsally (Fig. 4A, B). Anal tube elongate, 1.55 times longer than broad in dorsal view, broader at $3 / 5$ of total length; dorsal margin nearly straight in lateral view and strongly curved ventrally near apex (Fig. 4A, B); lateral margins sinuate in dorsal view (Fig. 4B); apical margin nearly straight in dorsal view (Fig. 4B); apical margin curved in posterior view (Fig. 4C); ventral margin reflexed near apex (Fig. 4A). Gonostyli (Fig. 4A) elongate with posterior half broader and strong subbasal constriction in lateral view; strong lateral tooth at about half length 

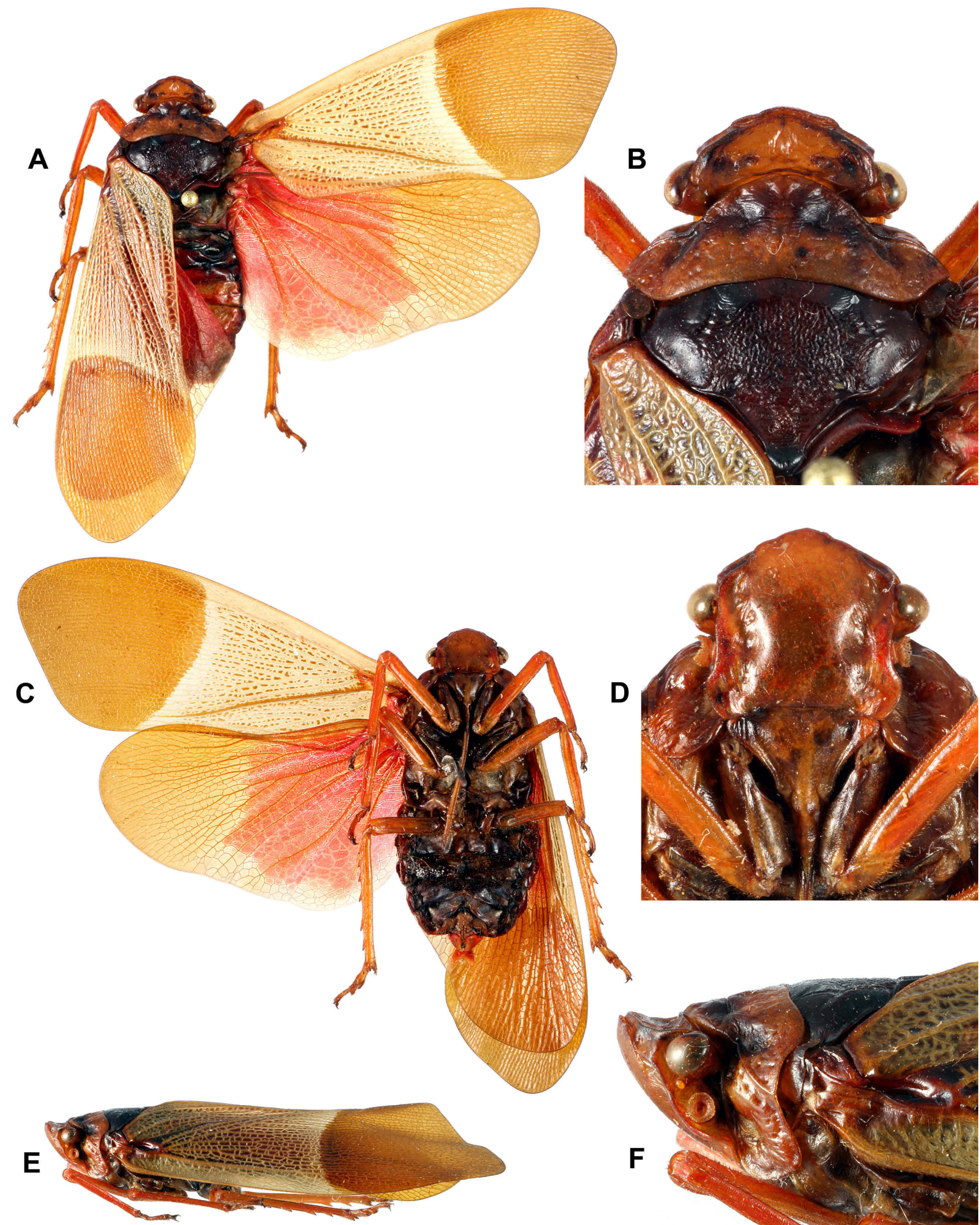

Fig. 6. Polydictya vietnamica Constant \& Pham, 2008, female, Thua-Thien Hue prov., A Roang, A Luoi, 25.iv.2009, leg. H.T. Pham (RBINS). A - habitus, dorsal view; B - head, pro- and mesonotum, dorsal view; C - habitus, ventral view; D - frons, normal view; E - habitus, lateral view; $\mathrm{F}$ - head and prothorax, lateral view.

directed antero-ventrally; apical margin nearly straight medially. Aedeagus (Fig. 4D, E) with endosomal process curved internally, laterally laminate and narrowing towards apex in dorsal view; dorsal margin with 6 teeth directed laterodorsally and a strong tooth directed dorsolaterally on mediodorsal margin. 


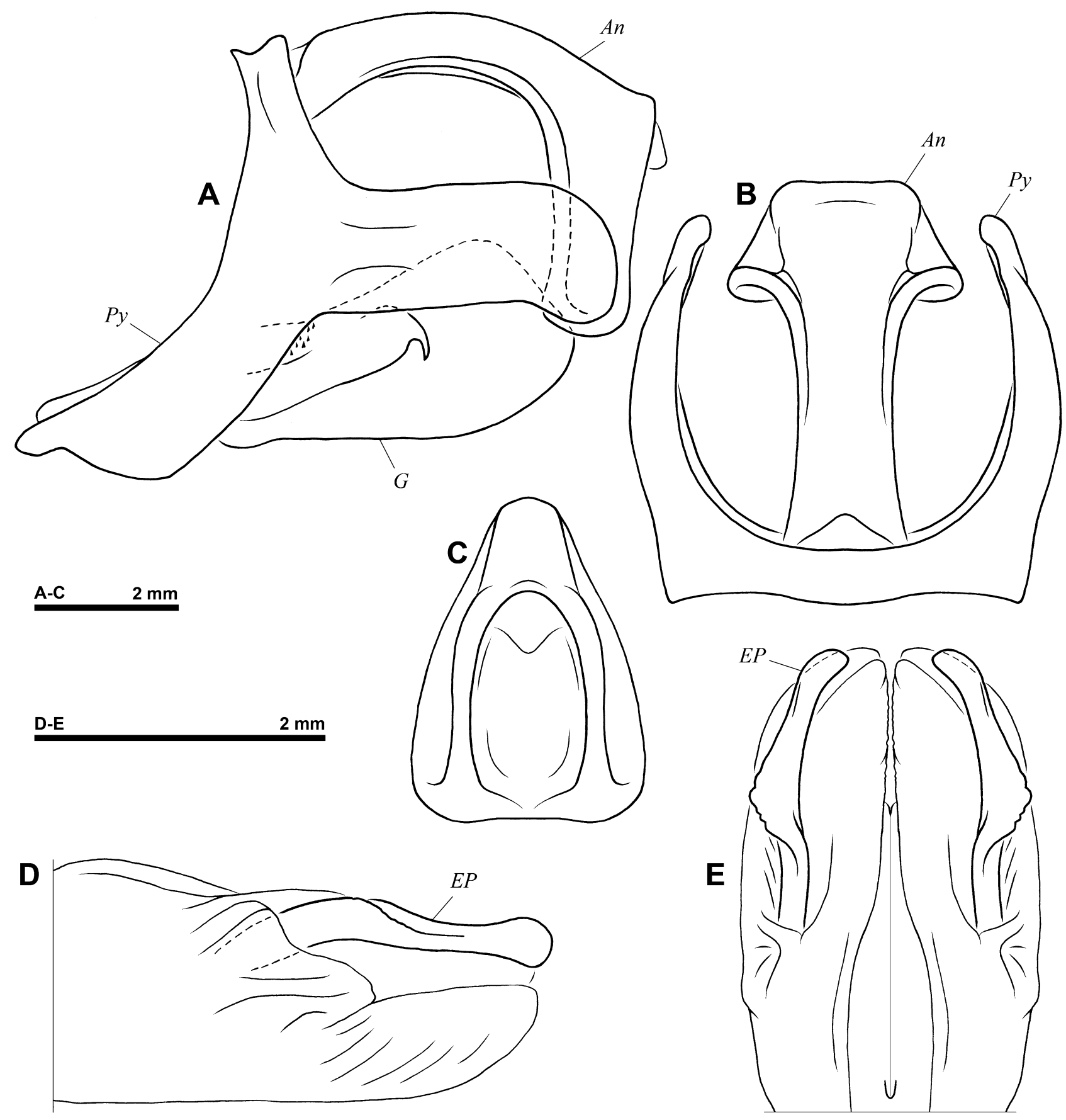

Fig. 7. Polydictya vietnamica Constant \& Pham, 2008, male genitalia. A - pygofer, anal tube and gonostylus, left lateral view; B - anal tube and pygofer, dorsal view; C - apex of anal tube, posterior view; D - aedeagus, lateral view; $\mathrm{E}-$ aedeagus, dorsal view. An - anal tube; $E P$ - endosomal process of aedeagus; $G$ - gonostylus; $P y$ - pygofer.

Type material. VIETNAM. Holotype $\widehat{\jmath}$ : [Coll. I.R.Sc.N.B.,

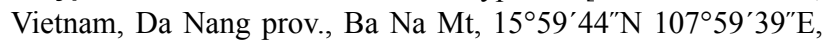
ix.2015, $1450 \mathrm{~m}$, local collector] (RBINS). Paratypes (5ㅇ): 1ㅇ: [VNMN.E.000000013, Bach Ma NP. Thua Thien Hue Prov., VIETNAM, 9/10/2015. Leg. Pham H.T.] (VNMN); 1 + same data except: VNMN.E.000000010 (RBINS); 1 ; : VNMN.E.000000011 (RBINS); 19: VNMN.E.000000012 (VNMN); 1 + : VNMN.E.000000131 (VNMN). Coordinates of Bach Ma National Park: $16^{\circ} 12^{\prime} \mathrm{N} 107^{\circ} 52^{\prime} \mathrm{E}$.

Etymology. The species is dedicated to Dr Patrick Grootaert, the head of Entomology at RBINS in acknowledgment for his long-standing support and help with our projects in Vietnam.
Distribution. Known from Central Vietnam, Bach Ma National Park and Ba Na Hills (Fig. 9A).

Biology. The specimens collected in Bach Ma National Park were sitting close to one another on the trunk of an unidentified species of tree (Fig. 5). At rest, they are very well camouflaged and difficult to spot.

\section{Polydictya vietnamica Constant \& Pham, 2008}

(Figs 6-8, 9B)

Polydictya vietnamica Constant \& Pham, 2008: 27 (type in RBINS) [described, illustrated, distribution map]. 

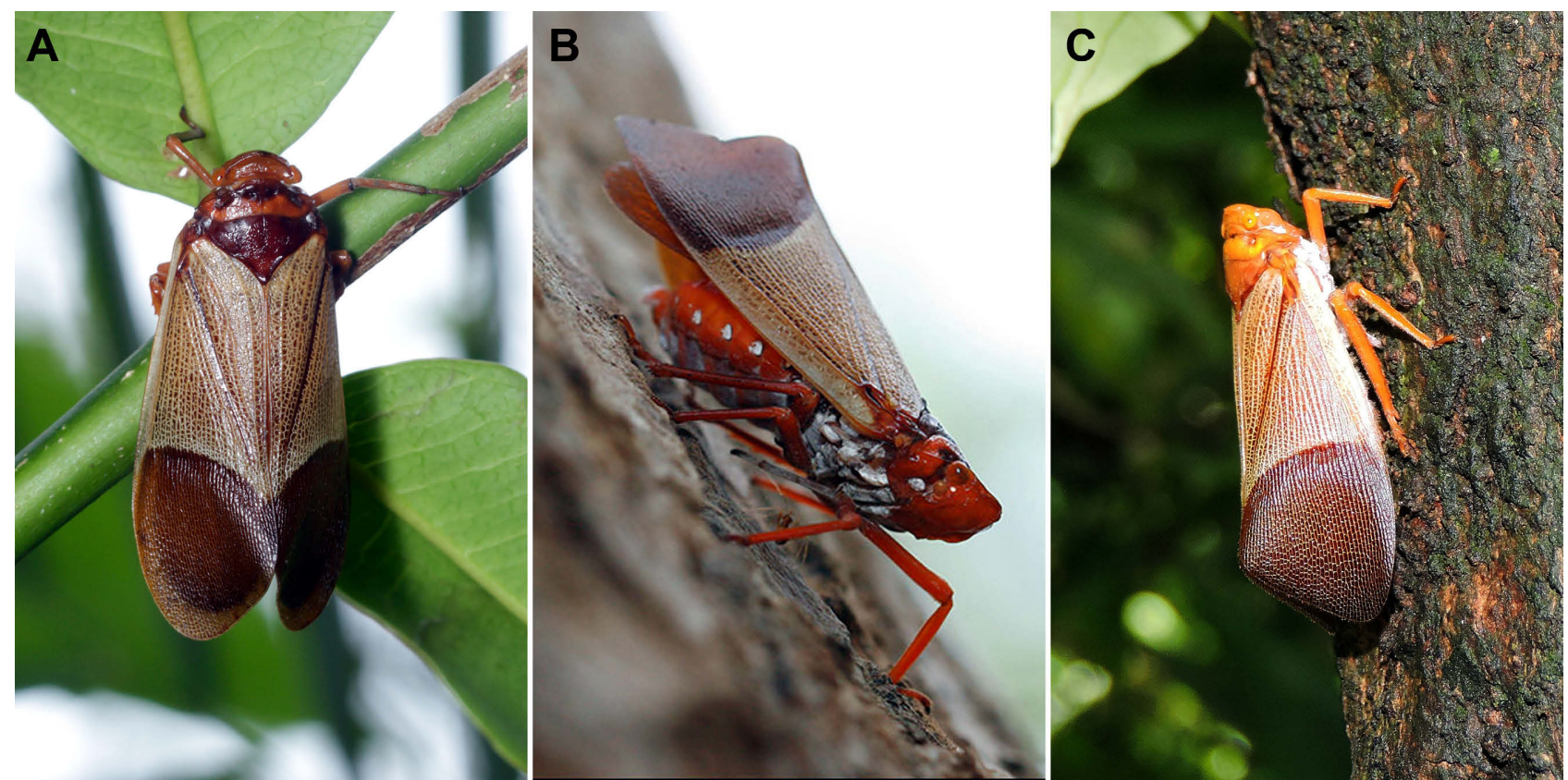

Fig. 8. Polydictya vietnamica Constant \& Pham, 2008, in nature. A - Thailand, KhaoYai National Park, 13.vii.2015 (photograph @ Ruangyot Hongsaeng); B - Thailand, Khao Soi Dao Wildlife Sanctuary, ix.2008 (photograph ๔ Bullung Siriphiphat); C - India, Meghalaya, Balpakram National Park, 3.vi.2015 (photograph @ Sachin Ranade).

Polydictya vietnamica: Constant 2009: 294 [key to Polydictya species with posterior wings red basally]; Constant et al., 2016 [to be searched for in Cambodia].

Male genitalia. Pygofer, anal tube and gonostyli red. Pygofer higher than long, with posterior margin showing a broad, elongate, laminate process at mid-height, directed medioposteriorly, posterior margin of process rounded; anterior margin of pygofer strongly concave in lateral view (Fig. 7A, B). Anal tube in dorsal view elongate, 1.54 times longer than broad, broader at $3 / 4$ of total length (Fig. 7B); strongly curved ventrally in lateral view and broader apically (Fig. 7A); apical margin slightly concave in posterior view (Fig. 7C); lateral margins diverging from base to apex in dorsal view (Fig. 7B). Gonostyli (Fig. 7A) elongate, 1.70 times longer than high in lateral view with posterior half broader in lateral view; strong lateral tooth directed posteroventrally at about half of length, under dorsal margin; apical margin oblique with dorsal and ventral angles rounded; dorsal margin slightly curved and ventral margin broadly rounded in lateral view; basal dorsal field of small spines directed dorsally. Aedeagus (Fig. 7D-E) with endosomal processes elongate with apex slightly clavate and curved internally; dorsolateral lamina on median $1 / 3$, broader near base and with lateral margin irregular; lamina sinuate in lateral view.

Material examined. Type material. VIETNAM. Holotype $q$ : [Coll. I.R.Sc.N.B., Vietnam, Quang Tri prov., Dakrong district, Huc Nghi commune, 6/V/2005, 265 m, Ho. 1472, leg. H.T. Pham] (RBINS).

Additional material. 1 $ᄋ$ : Vietnam, Thua-Thien Hue prov., A Roang, A Luoi, 25.iv.2009, leg. H.T. Pham (RBINS); 2 \%: Vietnam, Cat Ba National Park, 17.vii.2003, leg. H.T. Pham (VNMN); 1 $\delta^{\widehat{N}}$ : Vietnam, Pleiku, "Nui Hong Kong" (see note below), iv.1967, leg. G.W. Ulrich (UDCC).
Note. We have not been able to find a place named "Nui Hong Kong", but near Pleiku, there is "Nui Ham Rong" (Gia Lai province), a mountain close to Camp Enari, an American military base camp established in September 1966 and closed in April 1970 (Wikipedia, 2016). The wrong name on the specimen's label is probably a transcriptional error.

Material examined only on photographs taken in nature. THAILAND: 1 ex. (Fig. 8A), Thailand, Khao Yai National Park, 13.vii.2015, Ruangyot Hongsaeng; 1 ex. (Fig. 8B), Thailand, Khao Soi Dao Wildlife Sanctuary, ix.2008, Bullung Siriphiphat. INDIA: 1 ex. (Fig. 8C), India, Meghalaya, Balpakram National Park, 3.vi.2015, Sachin Ranade.

Distribution. This species is recorded from Vietnam, Thailand (new country record to be confirmed) and northern India (new country record to be confirmed) (Fig. 9B).

Note. The data from Thailand and India are based on photographs as no collection specimens from these countries are available. Confirmation of the presence of this species based on the examination of specimens is still pending (see Discussion).

\section{Identification key to the species of Polydictya from the Indochinese region}

Note. The couplet 2 concerning P. basalis and P. johannae is based on the key given by Lallemand (1963). The latter species was described based on a female specimen and still requires a study of the male genitalia in order to assess its relation to $P$. basalis.

1 Hind wings with a rectangular basicostal bluish-white marking...

- Hind wings without rectangular basicostal bluish-white marking...

2 Hind wings red basally .......

- Hind wings brown basally ........... johannae Lallemand, 1956 


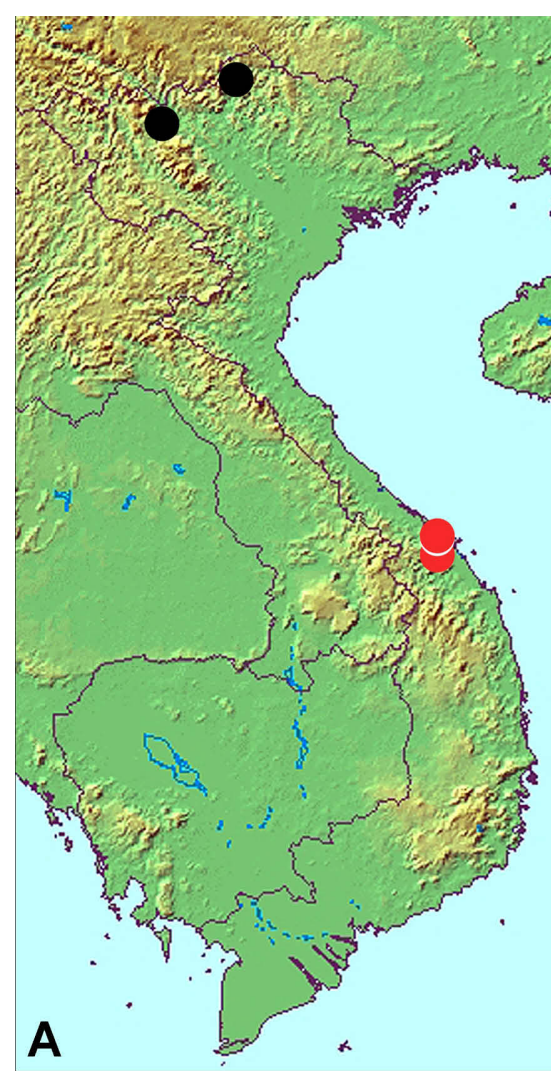

P. drumonti sp. nov.

P. grootaerti sp. nov.

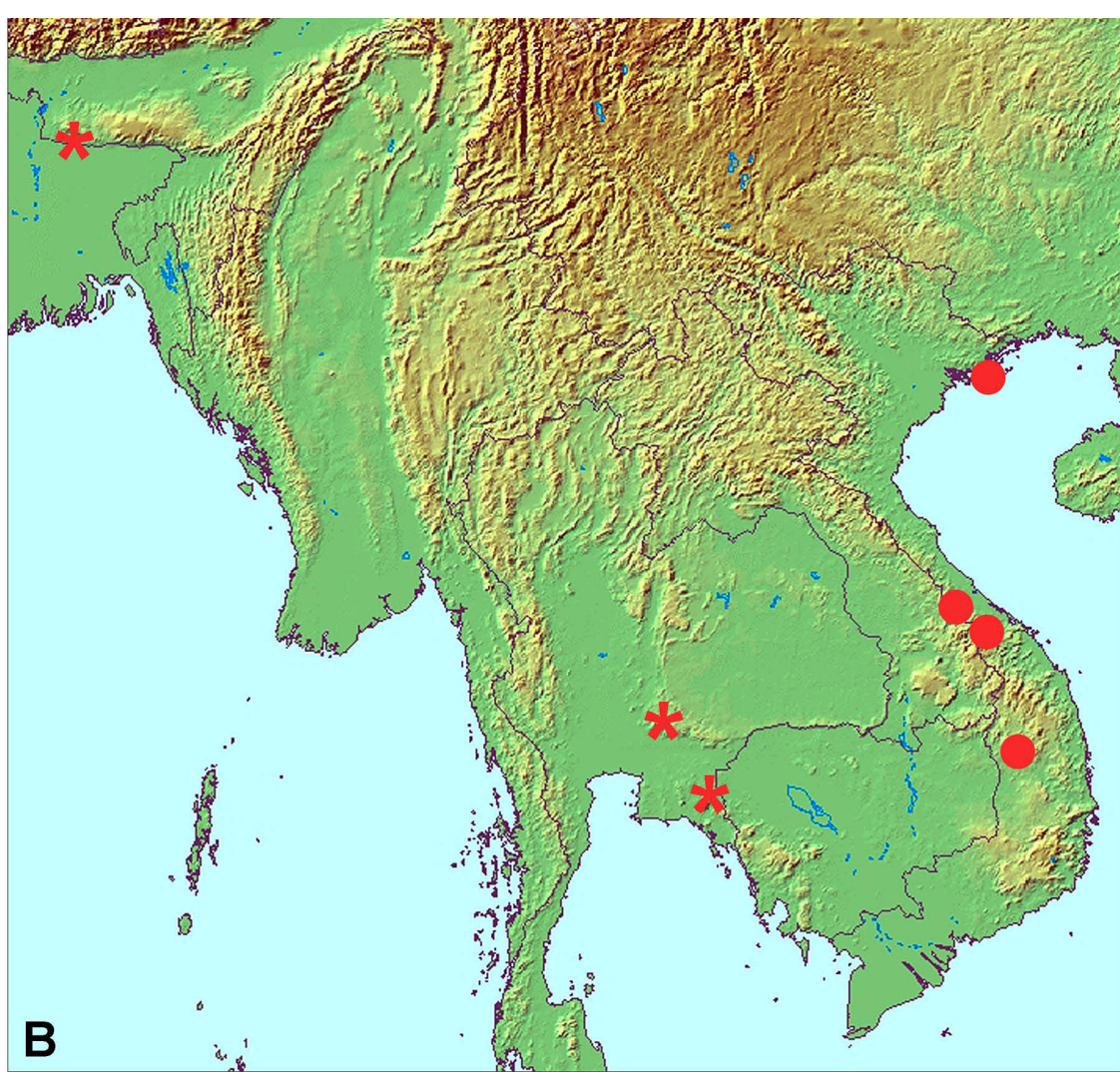

P. vietnamica Constant \& Pham ( $*=$ data from photographs)

Fig. 9. Distribution maps. A - P. drumonti sp. n. and P. grootaerti sp. n.; B - P. vietnamica Constant \& Pham, 2008.

3 Anterior and middle legs red

4

- Anterior and middle legs brown to black, often with a paler ring on tibiae

4 Basal half of tegmina with large black markings, posterior half mostly black; tegmina narrow, about three times as long as broad. P. tricolor (Westwood, 1845)

- Basal $2 / 3$ of tegmina without large black markings, apical $1 / 3$ brown; tegmina rather broad, less than 2.5 times as long as broad ........................... vietnamica Constant \& Pham, 2008

5 Hind wings largely bright red basally with some small black spots in the red area; abdomen mostly black dorsally ......

P. drumonti sp. $\mathrm{n}$

- Hind wings largely bright red or orange basally without small black spots; abdomen red or red with middle black dorsally .

6 Hind wings largely bright orange with basal bright red marking; abdomen red with middle black dorsally

P. grootaerti $\mathrm{sp} . \mathrm{n}$

- Hind wings largely, uniformly, bright red or bright orange; abdomen entirely red dorsally

P. chantrainei Nagai \& Porion, 2004

\section{DISCUSSION}

Seven species of Polydictya are currently recorded from the Indochinese Peninsula, with three of them described from Vietnam within the last 8 years.

Recent research and additional data based on photographs have also greatly extended the recorded distribution of $P$. vietnamica. The species was described based on a single female from Central Vietnam but is apparently widespread in continental Southeast Asia, with a range extending westwards to Thailand and India. All photographic data of this species were obtained through social media on the internet, on Facebook pages dedicated to insects and nature (see also Constant et al., 2016 for another example of the improvement of Lanternflies knowledge through the use of social networks).

However, the identification of Polydictya species requires confirmation based on the colouration of the hind wing and dorsum of the abdomen as well as the male genitalia, especially when data is recorded for areas far away from the previous distribution. For example, based on photographs of living specimens, $P$. grootaerti $\mathrm{sp}$. n. could be easily confused with $P$. chantrainei (see also Constant, 2009 for an illustration of $P$. chantrainei). In conclusion, collecting specimens to accurately document the species (males and females whenever possible) is highly recommended, and authorities should encourage this practice by citizen-scientists providing they collaborate in scientific projects. This is of great importance in order to build scientifically based faunistic lists and databases, e.g., for protected areas.

ACKNOWLEDGementS. We thank C. Bartlett (UDCC), A. Drumont (RBINS), R. Hongsaeng (Thailand), S. Ranade (India), B. Siriphiphat (Thailand) and M. Webb (BMNH) for providing specimens, photographs or data; N. Makbun for his kind help in 
translating Thai language; J. Bresseel (collaborator, RBINS), P. Limbourg (RBINS), P. Grootaert (RBINS) and Hoang Vu Tru (Institute of Ecology and Biological Resources, Hanoi, Vietnam) for their long-lasting help and support of our work; M. Wilson (National Museum of Wales, Cardiff, UK) and P. Štys (Faculty of Science, Charles University, Prague) for their comments on this manuscript. This paper is a result of our project "A step further in the Entomodiversity of Vietnam" supported through a grant issued by the capacity building Programme of the Belgian Global Taxonomic Initiative National Focal Point that runs under the CEBioS programme with financial support from the Belgian Directorate-General for Development Cooperation (DGD). The present study was also partially supported by the National Foundation for Science and Technology Development (NAFOSTED106-NN.05-2016.04), Vietnam.

\section{REFERENCES}

AtKinson E.T. 1885: Notes on Indian Rhynchota. No. 4. $-J$. Asiat. Soc. Beng. 54: 127-158.

Bosuang S., Audibert C. \& Porion T. 2015: Two new Polydictya from Borneo (Hemiptera: Fulgoromorpha: Fulgoridae). Faunitaxys 3(3): 1-4.

BouRgoIn T. 2016: FLOW (Fulgoromorpha Lists on the Web): A World Knowledge Base Dedicated to Fulgoromorpha. V. 8 , Updated. URL: http://hemiptera-databases.org/flow/ (last accessed 2 Sep. 2016).

Chew Kea Foo S., Porion T. \& Audibert C. 2010: Cinq nouveaux Fulgoridae asiatiques (Hemiptera: Fulgoromorpha). - Les Cahiers du Musée des Confluences - Etudes Sci. 1: 51-64.

Constant J. 2004: Révision des Eurybrachidae (I). Le genre Amychodes Karsch, 1895 (Homoptera: Fulgoromorpha: Eurybrachidae). - Bull. Inst. Roy. Sci. Nat. Belg. 74: 11-28.

Constant J. 2009: A new species of Polydictya from Sumatra and notes on P. chantrainei Nagai et Porion, 2004 (Hemiptera: Fulgoromorpha: Fulgoridae). - Ann. Zool. (Warszawa) 59: 293-296.

Constant J. 2010: A new species of Polydictya from Lombok (Hemiptera, Fulgoromorpha, Fulgoridae). - Nouv. Rev. Entomol. 26[2009]: 155-161.

Constant J. 2015: The Lanternfly genus Polydictya (Hemiptera: Fulgoromorpha: Fulgoridae) from Sulawesi and neighbouring islands, with the description of three new species. - Eur. J. Taxon. 110: 1-19.

Constant J. 2016: Two new species of Polydictya from Borneo and Siberut, and notes on P. chewi Nagai \& Porion, 2004 and P. tanjiewhoei Bosuang, Audibert \& Porion, 2015 (Hemiptera: Fulgoromorpha: Fulgoridae). - Belg. J. Entomol. 43: 1-17.

Constant J. \& Pham H.T. 2008: A new species of Polydictya from Vietnam (Hemiptera, Fulgoromorpha, Fulgoridae). - Nouv. Rev. Entomol. (N.S.) 25(1): 27-31.

Constant J., Phauk S. \& Bourgoin T. 2016: Updating lanternflies biodiversity knowledge in Cambodia (Hemiptera: Fulgoromorpha: Fulgoridae) by optimizing field work surveys with citizen science involvement through Facebook networking and data access in FLOW website. - Belg. J. Entomol. 37: 1-16.

Distant W.L. 1888: An enumeration of the Rhynchota received from Baron von Müller, and collected by Mr. Sayer in New Guinea during Mr. Cuthbertson's expedition. - Trans. Entomol. Soc. Lond. 1888: 475-489.

Distant W.L. 1906: The Fauna of British India, Including Ceylon and Burma. Rhynchota. Vol. 3. Taylor \& Francis, London, 462 pp.

Distant W.L. 1918: The Homoptera of Indo-China. - Ann. Mag. Nat. Hist. Lond. (Ser. 9) 1: 196-200.

GerstAeCKer C.E.A. 1895: Ueber einige bemerkenswerthe Fulgorinen der Greifswalder zoologischen Sammlung. - Mitt. Naturwiss. Ver. Neu-Vorpomm. Rügen 27: 1-50.

GuÉRIN-MÉneville F.E. 1844: Insectes. In Cuvier G. (ed.): Iconographie du Règne Animal. J.B. Baillière, Paris, London, pp. 355-370.

JACOBI A. 1910: 12. Hemiptera. 7. Homoptera. In Sjöstedt Y. (ed.): Wissenschaftliche Ergebnisse der Schwedischen Zoologischen Expedition nach dem Kilimandjaro, dem Meru und den Umgebenden Massaisteppen Deutsch-Ostafrikas 1905-1906, unter Leitung von Prof. Dr. Yngve Sjöstedt. Vol. 2. P. Palmquists Aktiebolag, Stockholm, pp. 97-136.

KARSCH F.A.F. 1890: Afrikanische Fulgoriden. - Berl. Entomol. Z. 35(1): 57-70.

Kirkaldy G.W. 1902: Memoirs on Oriental Rhynchota. - $J$. Bombay Nat. Hist. Soc. 14: 46-58, 294-309, pls A-C.

KiRKALDY G.W. 1907: "Current criticism." — The Entomologist 40: $58-60$.

Lallemand V. 1963: Révision des Fulgoridae (Homoptera). Deuxième partie. Faunes asiatique et australienne. - Mém. Inst. Roy. Sci. Nat. Belg. (2e Sér.) 75: 1-99, pls 1-11.

Melichar L. 1903: Homopteren-Fauna von Ceylon. F.L. Dames, Berlin, $248 \mathrm{pp}$.

Metcalf Z.P. 1947: General Catalogue of the Homoptera. Fascicle IV Fulgoroidea. Part 9 Fulgoridae. North Carolina State College, Raleigh, 280 pp.

NAGAi S. \& Porion T. 1996: Fulgoridae 2: Catalogue Illustré des Faunes Asiatique et Australienne. Sciences Nat., Compiègne, 80 pp., 236 figs.

NAGAi S. \& Porion T. 2004: Fulgoridae 2, supplement 2: Nouveaux Fulgoridae d'Asie du Sud-Est. Hillside Books, Canterbury, 13 pp., 14 figs.

Schmidt E. 1907: Beitrag zur Kenntnis der Fulgoriden. Die Arten des Genus Myrilla Distant. — Stett. Entomol. Ztg. 68: 113-116. Schмidt E. 1912: Diagnosen neuer Fulgoriden Gattungen und Arten. - Stett. Entomol. Ztg. 73: 67-102.

STÅl C. 1866: Hemiptera Africana. Vol. 4. Hemiptera Homoptera Latr. Ex Officina Norstedtiana, Stockholm, 276 pp.

WALKER F. 1851: List of the Specimens of Homopterous Insects in the Collection of the British Museum. Part 2. British Museum (Natural History), London, $636 \mathrm{pp}$.

Received November 19, 2016; revised and accepted January 20, 2017 Published online June 2, 2017 